\title{
ACTION-ORIENTED LANGUAGE TEACHING: OPINIONS OF STUDENTS OF FRENCH ABOUT SHORT FILM SHOOTING PROJECT
}

\author{
Canan Aydınbek ${ }^{1 i}$, \\ Esra Başak Aydınalp ${ }^{2}$ \\ ${ }^{1}$ Anadolu University, \\ Department of French Foreign Language Education, \\ Eskişehir, Turkey \\ ${ }^{2}$ Erzincan Binali Yıldırım University, \\ Language Education Department, \\ French Language Teaching, \\ Erzincan, Turkey
}

\begin{abstract}
:
The aim of this study is to analyze efficiency of teaching French with a short film project and to reveal learners' opinion. In this study, case study, which is one of the qualitative research methods, was preferred. This study was conducted with 10 students of Anadolu University, Faculty of Education, French Language Teaching Department. The data is collected through observation and group interview techniques. Macro and micro tasks were assigned in order to develop learners' linguistic and extra linguistic skills during 8weeks. Furthermore, products such as scenario, banner, short-film etc. have also been analyzed as documented data. Observation and interview notes were coded by two researchers and 92\% reliability was achieved; 6 themes and 15 subthemes were thus forged. According to findings, the motivation of the participants increased. Possible reasons for this are the different and fun activities, creating a concrete product and feeling successful. In group work a positive synergy observed among good associates, but learners' discussion, co-deciding and cooperation skills need to be improved. Participants stated that their creativity, socio-cultural, self-learning and self-assessment skills have developed. In conclusion, project-based learning, supported by action-oriented approach, helps to increase student motivation, creativity, intercultural skills and autonomous learning skills.
\end{abstract}

Keywords: action-oriented approach, French language teaching, short film, project-based learning

i Correspondence: email caydinbek@anadolu.edu.tr, $\underline{\text { ebaydinalp@erzincan.edu.tr }}$ 


\section{Introduction}

Foreign-language teaching methods have distanced from traditional codes and evolved to fit the dynamic and action-driven conditions of modern age. Within that context language is seen as an active performance and social interaction tool. The approach that gained prominence in Common European Framework for Languages (CEFR, 2001:6) is Action-oriented Approach that is structured upon multi-lingualism and multiculturalism. This approach considers the user or learner of a language as a social actor equipped with the ability to perform a linguistic or extra linguistic task. The goal in performing these tasks is creating a final product. Learner, while communicating with a party, is analyzed on the basis of mutual interaction s/he formed rather than the effect created on the contacted persona during the process of product formation. In other words, communication is not limited with transference of a message to recipient and feedback from the contact, indeed, it is forming of a meaning as a result of reciprocal interaction. Inevitably language teaching process then evolves into a socio-cultural communication, interaction and activity between learner \& instructor and learner \& learner.

The approach adopted by CEFR (2001:9), "is an action-oriented one in so far as it views users and learners of a language primarily as 'social agents', i.e. members of society who have tasks (not exclusively language-related) to accomplish in a given set of circumstances, in a specific environment and within a particular field of action".

In Action-oriented Approach, language is valued as a social formation, interaction and action domain between humans and language teaching gained a new dimension. Activities and exercises are replaced with long-termed projects and activity plans and language acquisitions are analyzed not in isolation but in relation to social and cultural contexts

Learners acquire an intellectual feedback in view of their own educational processes. Another concept accentuated in CEF is "task" concept. Teaching of living languages which also entails communication skill is viable through performing activities occurring inside or outside of class environment within the routine of daily life. Rosen (2010: 488) argues that tasks and actions conducted inside or outside of classroom principally hold these traits: these tasks are mostly selected according to the objectives set by an instructor, performed by one or more learners and their completion involves an analysis of both content and format.

Puren (2006, quot. in Bagnoli, Dotti, Praderi, Ruel, 2010:6) determined numerous action-domains and explained them as below:

a) inviting learners to do a task and assessment based on a centric action (Task-based Learning),

b) learning and assessment through a scenario suggested by Linguistic Competency

Diploma designed entirely on the basis of action-oriented approach,

c) simulation-based learning,

d) learning via real projects. 
That is why, as argued by Bourguignon (2009:59), in action-oriented approach teaching process obeys the chart below in a self-renewing and rotating reason:

- Understanding to act: signifying the action with regards to situation, users and context,

- Acting to understand: through action, realizing whether or not the case being understood,

- By making itself clear, producing to make sense of the action: if the product is not comprehensible for the contact party, learner realizes some parts have not yet been understood and this realization turns into a novel educational object.

In action-oriented approach the emergent result is not only a given product; the said approach also affects learner motivation, capability in assessing formed-product, self-awareness, creativity and critical skills. In that sense, learners that unite through some interaction to solve a problem can gain an educational insight and feedback as regards a thoroughly-authentic product and on the formation processes of the final product. This feedback mirrors social, cultural and also linguistic attributes and by bonding a tie with real life, it is geared at empowering problem-solving skills of a learner while also gaining him/her a critical perspective.

The project-based approach is a way of thinking about teaching for a more effective learning. "Project-based learning is therefore a systematic process of acquiring and transferring knowledge during which the learner anticipates, plans and realizes, in a determined time, alone or with peers and under the supervision of a teacher, an activity observable which results, in an educational context, in an evaluable finished product." (Puren, 2013:6).

Kuduz (2019) has examined and analyzed the role of tasks in CEF action-oriented approach in French as a foreign language in which the authenticity of CERF tasks was criticized. It has been demonstrated that it is necessary to create communication scenarios to integrate Web 2 in order to execute these tasks in a Turkish context due to the lack of the use of French language in the Turkish society.

In the study entitled "An Application of the Action-Based Approach in French Language Teaching: A Qualitative Case Study" which was executed in a Turkish context, it was demonstrated that the action-based approach could be used effectively for the teaching/learning of a foreign language and that the application of the action-based approach not only constitute a gateway to motivate students to learn the language as a social actor but also to consolidate the social, cultural and linguistic components of foreign language teaching/learning through a collaboration established among students during courses (Aydoğu, Ercanlar and Aydınalp, 2017:779). There are very few studies on this subject in Turkey. Therefore, new studies with different samples and different variables can help test this theoretical framework mentioned above.

Within that context, in this study, course plans for one semester were prepared and learners were asked to write a scenario and shoot a short film by operating their creativity and critical thinking skills. In accordance with this objective, below-listed questions have been addressed:

1) What are the opinions of learners as regards short-film shooting experience? 
2) Within the scope of action-oriented approach, how does the short-film shooting task affect learner's motivation?

3) How does scenario writing or film shooting task affect learners' creativity?

4) How does group work conducted to perform the assigned tasks in this study affect the use of French language?

5) How does this experience affect learners' intercultural skills?

6) How does this experience affect learners' self-assessment and self-learning ability? This section should comprise a description of the general framework, definitions and principles, primary issues and controversies, background information and contexts, etc.

\section{Material and Methods}

Qualitative research method was employed in this study aiming to analyze the effects of short film project on learners' motivation, creativity, self-assessment and cooperative learning skills.

\subsection{Research Model}

This study has been designed as a case study. "A case study is in which researcher collects detailed and comprehensive data about real life, a current and limited system (a given case) or about multi-limited systems(situations) during a specific period through multi-information resources (for instance via observations, interviews, audio-visual materials, documents and reports). In this qualitative approach the aim is describing a situation or exhibiting situational themes" (Creswell, 2013:97).

\subsection{Data Collection Techniques}

In case studies (situation-based) data collection for a research can generally be comprehensive, in other words, observation, interview, documents and audio-visual materials could be conducive as data collection tools. For instance, Yin (2009, quot. in Creswell, 2015:100) suggests 6-types of data resources in the collection process: documents, archival records, interviews, direct observations, participant observations and a number of concrete works.

Thus, in this study data were collected through focus-group interviews and observation. Focus-group interview that aims to grasp the data generated as an effect of interaction between participants is delineated such by Yıldırım and Şimşek (2011:152) "conducted in a peaceful and welcoming setting; a series of discussions carefully planned in order to obtain insights toward a predetermined topic". Key objective in these interviews is to unveil participants' attitudes, feelings, beliefs, experiences and type of reactions that could go unnoticed by other methods. The data obtained from focus-group were supported via documents (short-length film, written scenarios and film banners) that represented outcomes or products of the tasks assigned to students during teaching process. Moreover, by also harnessing instructor's (researcher) direct and indirect observations, 
some sort of diversity was achieved through triangulation technique during data collection process.

In group interviews, questions that were asked to participants to discover their insights are as below;

1) What do you think about the short film shooting experience in terms of transferring in-class activities to real-life situations?

2) How did short film shooting practice affect your motivation?

3) How would you describe effects of this experience on your imagination and creativity?

4) In your point of view, what are the advantages and disadvantages of team-work?

5) After this practice, what are the points you realize about French culture and your own culture?

6) How did this practice affect to your linguistic development?

7) How did these activities affect your self-assessment and autonomous learning mechanism?

\subsection{Participants}

This study was conducted in Anadolu University, Faculty of Education, French Language Teaching Department within the scope of French Literature and Film Adaptations course. Participants were formed by 10 students who selected the said course during fall term of 2018/2019 academic year. All of the participants had been learning French for 3 years including preparatory year and their French competency levels were categorized as B1+, and B2.

\subsection{Data Collection Process}

In data collection, learner presentations (short-length film, written scenarios etc.), learner diaries, researcher diaries, indirect and direct observation stages to be conducted by the researcher were indicated. Initially three short-length films in French were demonstrated to learners to introduce the nature of a short-length film and it was aimed to raise learners' curiosity subsequent to viewing the films. Next one of the researchers provided the learners detailed information regarding film show and techniques while the second researcher observed the whole process directly and indirectly. These observations were jotted down on researcher diaries which were then evaluated in the process of data analysis. Concordantly macro and micro-level duties and tasks of learners were identified. Total length of this project lasted 8 weeks. Weekly-activity plan is as portrayed in the table below. 


\begin{tabular}{|c|c|}
\hline \multicolumn{2}{|r|}{ Table 1: 8-Week Activity Plan } \\
\hline Week & Activities \\
\hline 1 & $\begin{array}{l}\text { Introducing short film } \\
\text { Demonstrating three short-length films in French language } \\
\text { Clarifying the differences between short-length film and full-length film }\end{array}$ \\
\hline 2 & $\begin{array}{l}\text { Forming groups of } 3-4 \text { participants } \\
\text { Exploring and expanding vocabulary on cinema } \\
\text { Devising a draft for short-length film scenario }\end{array}$ \\
\hline 3 & $\begin{array}{l}\text { Reviewing written scenarios } \\
\text { Completing character forms prepared by the teacher }\end{array}$ \\
\hline 4 & $\begin{array}{l}\text { Teaching of camera actions and use of light } \\
\text { Detecting players, location, space, time }\end{array}$ \\
\hline 5 & $\begin{array}{l}\text { Rehearsing } \\
\text { Shootings }\end{array}$ \\
\hline 6 & $\begin{array}{l}\text { Revision of shootings and re-acting certain scenes } \\
\text { Editing }\end{array}$ \\
\hline 7 & $\begin{array}{l}\text { Preparing a film banner and title sequence } \\
\text { Presenting created short films in front of an audience group } \\
\text { Writing reviews on short films }\end{array}$ \\
\hline 8 & Focus-group interviews with participants. \\
\hline
\end{tabular}

\subsection{Reliability and Validity of the Data Analyses}

According to Miles and Huberman $(1994,64)$, the eventual inter-code agreement should be up in the $\% 90$ range. Therefore, data is coded by two researchers in order to validate the results. The reliability has been calculated using the formula as stated by Miles and Huberman (1994:64): dividing the number of agreements by the total number of agreements plus disagreements.

\subsection{Data Analysis}

Data of this research is compiled of; concrete products (written scenarios, film shooting activities, film review texts, film banners) that would unravel, upon completion of the tasks designed within the scope of French Literature and Film Adaptations course, the indirect and direct observations of researchers in class hour, researcher diaries and transcription of group interviews conducted with the learners at the end of course term. Diversity of obtained data evidences the validity of research. To analyze all of these documents, products and data forged with interview outcomes initially themes were designated independently by two experts and to ensure reliability of research consensus was tied on these themes. In the second stage, these themes were interpreted and then reported. The themes were not pre-detected but came to the surface at the time of analysis. 


\section{Results and Discussion}

In the analysis of data, six main themes obtained: short film experience, motivation, group work, creativity, assessment and French use. These themes were then divided into fifteen subthemes which are as listed in the Table 2 below:

Table 2: Main Themes and Sub-themes

\begin{tabular}{ll}
\hline Main Themes & Sub-themes \\
\hline Short-film & $\begin{array}{l}\text { Shooting and editing techniques } \\
\text { Scenario writing }\end{array}$ \\
\hline Using French & $\begin{array}{l}\text { Vocabulary and intonation } \\
\text { Practical language use } \\
\text { Intercultural awareness }\end{array}$ \\
\hline \multirow{3}{*}{ Motivation } & $\begin{array}{l}\text { Feelings } \\
\text { Product } \\
\text { Intrinsic motivation }\end{array}$ \\
\hline Creativity & $\begin{array}{l}\text { Exploring innovations } \\
\text { Limitations }\end{array}$ \\
\hline Group work & $\begin{array}{l}\text { Tolerance-consensus } \\
\text { Team spirit } \\
\text { Cooperation }\end{array}$ \\
\hline Assessment & Grade anxiety \\
& Assessment criteria
\end{tabular}

Themes and sub-themes attained at the end of analysis have been respectively explained hereinafter and sample statements of participants during focus-group interviews have been noted. Since quoted statement samples are transferred in oral language, grammatical errors have remained unchanged. In the quotations, proper nouns are indicated by an initial only.

\subsection{Short-film Experience}

\subsubsection{Scenario Writing and Shooting Techniques}

As regards this experience, some of the learners reported that they found this application inadequate since they were able to implement only a small amount of shooting techniques they had learnt; some students claimed to have learnt writing techniques to a large extent and that although it seemed quite a big challenge at first, writing a French scenario also had motivating aspects in their experience:

“... to be honest we did not have much opportunity to practice what we have learnt. I mean our subject was a bit problematic too... we cannot create something that necessarily demonstrates all of the things we've learnt, after all it lasted fifteen minutes only... So, I really don't think we can associate this course with the world outside." (S.1)

"I believe we used... because for example I had no idea about scenario types before. So that was a first-time experience for me, scenario writing and I was a bit tense when I found out 
that we were going to write a scenario. We learnt the differentiation between French and American and in the course, we felt really comfortable in writing process, under normal circumstances could I never ever write a scenario but since I learnt the way to write in this course, I put what I learnt into action." (S.2)

In this course, learners gained an opportunity to simultaneously experience two salient components of action-oriented approach by concurrently performing in-class linguistic tasks (short-story-synopsis- and scenario writing, banner designing, presenting etc.) and short-length film shooting and editing which are extra linguistic activities. To put this differently the task assigned to them was not limited only with language use; for instance, certain strategies such as scenario writing technique or learning how to implement certain camera angles corresponded to extra linguistic skills. Therefore, task performance not only focused on correct use of target language but also motivated the learner to perform action as a social actor by developing a range of different skills.

\subsection{Using French}

The views of interview participants about using French can be elaborated under three headings below;

\subsubsection{Vocabulary and Intonation}

First of all, learners reported that scenario writing task affected their French learning process in a positive direction and they, at most, gained a chance to practice vocabulary and daily use of French language. Also, unlike traditional teaching activities, they realized how intonation indeed mattered.

“...We learnt new words..." (S. 1)

"I personally think that since we were going to shoot a film and we took this task seriously or at least since it was our own film, we tried to pay more attention to certain aspects for instance accent. When talking to friends who did not know anything in French and when we tried to tell them some things, we still paid heeds to intonation. So, in addition to teaching new vocabulary, this activity also motivated us to truly pay attention to accent. That is what I learnt most... we for example tried more to speak like French people do. And we also discovered our deficiencies in this activity." (S. 2)

\subsubsection{Spoken Language (Daily language) vs. Formal Language}

Further to that, since learners had a chance for the first time to use the language, they have been learning outside classroom environment to meet a totally different objective than education, which was indeed a real opportunity to practice real language. They reported that informed awareness could thus be driven in relation to the distinction 
between practical language use and grammatically-correct (structured language) use of language.

"In my opinion that was our first experience in using the language in its true sense because in other lessons all we do is learning new things nonstop and writing, writing all the time. Thankfully this time we were able to actually put what we learnt into practice." (S. 1)

"For instance, in our scenario there was a line, "À cause d'une retard de 5 minutes" but Ç. said this line all the time like "à cause de bruit. That is because in other lessons neighbours' loud noise is termed as "à cause de bruit" so that is the way engrained in his mind. So, as he also said we could finally use French the way it is used in daily life." (S. 2)

\subsubsection{Intercultural Awareness}

Participants reported that while writing scenario, they had to opt for translation and tried to analyse French mindscapes in order to discover how some idioms are used. Students reported that by comparing ways of expression in two languages they had an opportunity to improve their translation skills and intercultural awareness. Observation findings are also in parallel with this result. While thinking about how to best express their ideas during scenario writing, learners gain a chance to interact with the teacher and members of his/her group and also by conducting internet researches they tried to improve their mutual interaction skills.

"In terms of daily-French for example we realized that when we thought in Turkish and translated into French the meaning was transformed in a mot à mot translation, so we had to conduct further research. In fact, we had to get more into real French, how the language is used, idioms etc., in order to empower emotions because since we were not writing an ordinary text, we normally had to convey the emotions, so we had to do further analysis." (S. 1)

\subsection{Motivation}

Learners agreed that this practice positively changed their motivation level. As shown in interview and observation findings, below-specified feelings were detected as regards motivation: the feeling of achievement, uniqueness, joy, fun, creating a product.

Unlike traditional in-class educational activities, performing a non-class activity different from in-class activities is featured as a motivation-climber factor. It is an attested fact that a fun activity that provides pleasure to its practitioners is already a motivating activity on its own. Lastly creating a concrete product at the end of this application invokes among learners the feeling of completing a mission successfully. Once they experience this activity as a group, aside from abiding by some of the instructions given by the teacher, this has been a truly-personal experience for them since they had the 
freedom of decision-making and implementing in the course of application. In that sense, learners moved beyond their passive-listener role but rather embraced an active role as a social actor. Acting as an independent character helped them to significantly internalize their task and assume responsibility.

"It increased my (Motivation) because when you try to learn the use of language about something you are already interested in, you can become much more motivated so I was really able to learn novel things too. Since in scenario writing we tried to write in daily language, we also had a chance to practice this part as well. That is the case." (S. 1)

"It was an experience for us, a bit amateurish but still we believe it was a good experience for us. We learnt new words, we really had fun, so in a sense it was a difference for us." (S. 2)

Concepts that surfaced about motivation are: feelings, product, difference, personal experience.

\subsection{Creativity}

Learners reported that through this experience they had to think about things they had never considered before and forced to activate their imaginative powers and that it was only viable through intrinsic motivation and that their critical thinking skills would develop in a positive way within the context of group work.

However, according to a few participants, limited time and opportunities also limited their creativity skills.

\subsection{Group Work}

Learners reported that working in groups of two, three or five nourished the tolerance and consensus skill they had, and they could realize the value of synergy that could create team spirit and they affirmed how in such activities, cooperation and task distribution would make all the difference. Next, they stated that in an interactive setting, team work increased creativity and motivation.

"...of course it helped us. As I said before, normally we wouldn't get together and discuss something like that but thanks to this task, we introduced this issue. I mean, disabled people, social life, and their living conditions in the midst of chaotic urban life..." (S. 1)

"...Well, for me, I was one of the lucky ones because in my group everyone was from those I already know so I felt more comfortable in my task. But you just can't help comparing it with real life, you imagine how to act in this situation in real life and how you are acting now." (S. 2) 
However, a problem emerged due to a disagreement among the members of a group; then the cause of problem had to quit the group.

\subsection{Assessment}

Some of the learners deemed that assessment of this practice to be graded by course instructor is something positive and motivating whereas some of the participants reported that when they have grade anxiety, they felt a greater tension and excessively worried about getting a good grade from the task.

"Well actually it affected positively because we took films in your office and you warned us about not to film the sceen in half ... Not in half but everything in full image, or else we would get a low grade. So, a positive effect and a deeper learning. Well..." (S. 1)

"It helps us be more attentive..." (S. 2)

\section{Recommendations}

Driven from this research hereby, below are some of the suggested issues to be explored in potential researches in future;

e) Integration of linguistic and extra linguistic activities to action-oriented approach,

f) Analyzing self-awareness and especially responsibility-taking skills in learning processes as regards learners deemed to be social actors in action-oriented approach,

g) Based on action-oriented approach, identifying conditions for autonomous learning,

h) A range of activities likely to affect the level of learner motivation,

i) The way to support translation skills of learners through action-oriented approach,

j) Exploring impact of action-oriented approach on the creativity and critical thinking skill of learners,

k) Conducting detailed analyses to specify the effects of action-oriented approach on learners' perception towards their own culture and other cultures,

1) Investigating reciprocal interaction skills of learners as deemed to be essential in a group work,

m) In terms of learning process, effects of transferring of linguistic and a number of other skills acquired in classroom to outside of the classroom,

n) Applicable strategies suggested to feature personal differences among learners,

o) Analyzing learning strategies implemented by students in courses that are prepared in line with action-oriented approach,

p) Aside from linguistic knowledge and skill, examining the effect of this approach on learners' culture level. 


\subsection{Limitations and Implications}

This study was limited to the students of Department of French Language Education, at Anadolu University. All of the students were interested in cinema because they chose an elective course about cinema. However, the equipment and time required to improve their creative skills were limited. The researcher did not have the chance to supervise the shooting sessions of all groups due to limited time. Each group could not spare enough time to criticize the scenario written by other groups.

In terms of language development, the language used by students was limited to the products they produced. During scriptwriting and filming, a method could be found to enable students to use French in particular. In addition, the films made by the students were planned to be shown to all French students at the end of the project, but this could not be done. Students' grade anxiety affected their activities to a certain extent. These kinds of projects can be done in extra-curricular contexts and student anxiety could thus be reduced.

\section{Conclusion}

This study aimed to develop a project based on the theoretical pillars of action-oriented approach. Based on the data gathered after the observation and interviews, below are conclusions that we could drown;

1) What are the opinions of learners as regards short-film shooting experience?

According to the results of the interview and observations learners stated that they learned new words, focused on intonation and had the opportunity to use French as used in daily life. They also focused on extra linguistic activities such as shooting techniques and scenario writing rules. Participants think that the given tasks are different from the classroom activities they are used to.

2) Within the scope of action-oriented approach, how does the short-film shooting task affect learner's motivation? The learners think that this practice has increased their motivation. The reasons for this are: doing a fun and different activity, creating a concrete product and feeling of success.

3) How does scenario writing or film shooting task affect learners' creativity? The learners state that the given tasks lead to thinking about different topics and offer the opportunity to express themselves.

4) How does group work conducted to perform the assigned tasks in this study affect the use of French language? Group work requires compromise and task distribution.

- Team spirit creates synergy. The fact that group work is fruitful largely depends on the harmony among group members. That means people who are already close friends are inclined to be in the same group. It is detected that they would rather not be in the same group with those they anticipated to disagree and feel distant. The ability of learners to respect and discuss different thoughts should be developed. 
- Among group members, it has been witnessed that in most instances dominant characters could easily receive affirmation for their idea whereas people with a less assertive personality remained passive and avoided getting into any discussion. Although some group members valued assigned task as an opportunity to learn and explore unknown things, still, others were observed to take in a task about something they already had an idea about and preferred not to choose topics they knew little about. This is a finding that clearly manifests learners' personal differences when it comes to exploration and acquiring new information and skills.

5) How does this experience affect learners' intercultural skills? The learners stated that they gained cultural awareness, especially when it was necessary to express emotions.

6) How does this practice affect learners' self-assessment and self-learning ability? Findings demonstrated that learners were not adequately informed about assessment criteria. Moreover, it was detected that the practice contributed to selfassessment skills of learners in evaluating their task performance and improvement with the final product.

- We observed that throughout their past academic life, our participant group had almost never moved beyond traditional learner role that they were familiar with in classroom setting; hence they were, somehow, hesitant to act and autonomously perform an activity. We assume if the number of course activities in which learners are active is increased they can feel more comfortable in task performance.

- It is infeasible to draw generalizations with obtained data alone; however, in our research it was observed that not all learners had regular and planned study habits. Some failed to complete the given tasks on time and tried to finish piles of tasks in a short period of time.

- Performing an activity different from traditional in-class activities elevated learners' motivation. At this point we hold the belief that instead of simply analyzing functions of language, acting by using the language itself would be quite an effective method.

- Since group work is not quite a familiar way of study for learners, we believe that learners should develop themselves in relation to work sharing, reaching consensus upon discussion, conflict solution, trying to prove one's viewpoint against an opposite view etc.

- Material product created at the end of the project motivated learners to reach success and finish a task. In other approaches, success is mostly measured through exam grades whereas in project-based learning, learners have a chance to assess their own success by themselves. In another saying they gain an opportunity to develop autonomous learning and self-assessment skills.

- Since project-based learning grants the opportunity and freedom of selfexpression to learners, learners truly relish their learning process. Besides, by 
going beyond learner role to adopt social actor role, learners get ready for nonschool life and social life.

- In this practice, one of the deficient parts is the failure of learners to truly and accurately understand assessment-criteria and aims of the project. Since assessment process is one of the most critical stages of the project, it is suggested that future studies particularly take this issue into account. In addition, in macro and micro tasks linguistic and extra linguistic outcomes should be clearly specified. However, since this is an open-ended project predetermining targeted skills could be limiting; thus, observing the learners not only at the end of the process but rather throughout the process gains additional value.

Therefore, this study will function as a guide model for project-based teaching/learning sessions developed in the future. Applying theoretical information within the framework of action-oriented language teaching/learning approach and sharing greater quantities of concrete examples could offer help, in that sense, to teachers, learners as well as theoreticians alike.

In our research, we observed that throughout their past academic life, our participant group had almost never moved beyond traditional learner role that they were familiar with in classroom setting; hence they were, somehow, hesitant to act and autonomously perform an activity, this leaded us to question the authenticity of the tasks in a Turkish context. That conclusion is in line with that of Kuduz (2019).

We came to a similar conclusion whit that of Aydoğu, Ercanlar and Aydınalp, (2017: 779) and inferred that performing an activity different from traditional in-class activities increases learners' motivation and ameliorates and strengthens the teaching/learning process in our study.

\section{Conflict of Interest Statement}

The authors declare no conflicts of interests.

\section{About the Authors}

The author has been working as an assistant professor at Anadolu University, Faculty of Education, French Language Teaching program since 2005. The subject of her doctoral thesis is the use of French films in French Foreign Language Teaching. Some of her areas of interest are language acquisition theories, learning strategies, discourse analysis. Some of her publications are:

1. Aydinbek, Canan (2013). "The Effect of Awareness Concerning Cohesion Elements on Reading Skills of French Learners", International Journal of Global Education IJGE 1, 21-26.

2. Aydınbek, Canan (2014). “L'Autoévaluation et une Comparaison Entre l'Expression Orale de Quelques Aprenants de Français et Celle d'un Natif", Synergies Turquie, 7, 13-24. 
3. Aydinbek, Canan (2015). “Language Learning Strategy Usage of French Teacher Candidates", İJLA 3 (9), 233-250.

4. Aydinbek, Canan (2015). French Learners' Opinion about the Effect of Study Abroad Experience on Language Learning. Uluslararası Eğitim Bilimleri Dergisi (INES), 2(5), 131-140.

5. Canan Aydinbek, Hatice Aygün, (2018). La Perspective Actionnelle a la Lumière des Theories d'Acquisition : Analyse Comparative de Deux Methodes de FLE. Diyalektolog Sosyal Araştırmalar Hakemli Dergisi, 18, p. 13-35. Doi: 10.22464/diyalektolog.219.

6. Aydınbek, C., Başol, Y. (2019). Anadolu Üniversitesinin Çift Dilli Öğrencilerinde Fransızca Kullanımı ve Fransızca Yazılı Anlatım Becerisi. Anadolu Üniversitesi Eğitim Fakültesi Dergisi, 3 (3), 174-190

7. Aydınbek, C. (2011). “Le Cinéma : Document Authentique dans l'Enseignement du FLE", Éditions Universitaires Européennes, Sarrebruck.

\section{References}

Alrabadi, Elie (2012). Pour l'introduction de la perspective actionnelle basée sur la réalisation des tâches communicatives en classe de langue étrangère, Synergies Canada, No. 5.

Aydoğu, C., Ercanlar, M. \& Aydınalp, E. B. (2017). Fransızca Yabancı Dil Öğretiminde Eylem-Odaklı Yaklaşıma Dayalı Bir Uygulama Örneği: Nitel Bir Durum Çalışması, Hacettepe Üniversitesi Ĕ̆itim Fakültesi Dergisi, 32(4), pp. 760-779

Bagnoli, P., Dotti, E., Praderi, R., Ruel, V. (2010). La perspective actionnelle: Didactique et pédagogie par l'action en Interlangue. ANEP foro Langes. http://www.doscubos.com/clientes/3fla/ponencias/002.pdf accessed 25 June 2019.

Bento, M. (2013). Regards théoriques sur la perspective actionnelle dans l'enseignement des langues en France, Éducation Didactique, 7/1. Retrieved from https://educationdidactique.revues.org/1404 accessed 23 mars 2019. doi: 10.4000/educationdidactique.1404

Bourguignon, C. (2009). L'apprentissage des langues par l'action. L'approche actionnelle dans l'enseignement des langues. Paris : Edition Maison des langues, 2e édition révisée et enrichie, p. 49-78.

Brunelière, J.-F., Oliveira, C., L. P. (2016). La pédagogie de projet en cours de FLE : expérience dans un collège brésilien. Revista Letras Raras, 5, 5, 100-114. Retrieved from

https://www.researchgate.net/publication/334692803 La pedagogie de projet e

n cours de FLE experience dans un college bresilien,

doi: 10.35572/rlr.v5i3.701

Büyüköztürk, Ş., Kılıç Çakmak, E., Akgün, Ö., A., Karadeniz, Ş., Demirel, F. (2018). Bilimsel Araştırma Yöntemleri, Ankara : Pegem Akademi Yayıncılık. 
Conseil de l'Europe (2001). Cadre Commun de Reference pour les Langues, Apprendre, Évaluer, Enseigner, Paris: Didier.

Coste, D. (2010). Tâche, progression, curriculum. The Canadian Modern Language Review / La revue canadienne des langues vivantes, Volume 66, (4), pp. 499-510. https://www.muse.jhu.edu/article/390804.

Creswell, J. (2013). Nitel Araştırma Yöntemleri (Bütün, M., Demir, S. B.çev.). Ankara: Siyasal Kitabevi.

Creswell, J. (2015). Educational Research: Planning, Conducting and Evaluating Quantitative and Qualitative Research. Pearson.

Creswell, J. (2017). Nitel Araştırmacılar İçin 30 Temel Beceri (Özcan H. çev.) Ankara: Anı Yayincilik

Ellis, R. (2003). Task-based Language Learning and Teaching, Oxford: Oxford University Press.

Griggs, P. (2009). À propos de l'articulation entre l'agir de l'usage et l'agir de l'apprentissage dans une approche actionnelle : une perspective sociocognitive. L'approche Actionnelle dans l'Enseignement des Langues. Paris : Edition Maison des langues, $2^{\circ}$ édition révisée et enrichie, pp.79-100.

Güler, A., Halıcıoğlu, M. B., Taşğın, S. (2013). Nitel Araştırma Yöntemleri. Ankara: Seçkin yayıncilik.

Hamez, M.-P. (2012). La pédagogie du projet : un intérêt partagé en FLE, FLS et FLM. Le Français Aujourd'hui, 176(1), 77-90. Retrieved from https://www.cairn.info/revuele-francais-aujourd-hui-2012-1-page-77.htm accessed 10 mars 2020, doi: 10.3917/lfa.176.0077.

Kuduz, E. (2019). L'utilisation des tâches dans l'enseignement du fle, Mémoire de Master, Département de Didactique des Langues Étrangères Programme de Didactique du Français Langue Étrangère, Ankara.

Miles, M. B., \& Huberman, A. M. (1994). Qualitative data analysis: An expanded sourcebook. (2nd ed.). Thousand Oaks, CA: Sage Publications.

Punch, K. (2005). Introduction to Social Research Quantitative and Qualitative Approaches. 2nd Edition, London: Sage.

Puren, C. (2006a). De l'Approche communicative à la perspective actionnelle. le Français dans le Monde, No.347, pp. 37-40.

Puren, C. (2006b). Explication de textes et perspective actionnelle : la littérature entre le dire scolaire et le faire social. www.aplvlanguesmodernes.org/spip.php?article389 accessed 13 january 2018.

Puren, C. (2014). La pédagogie de projet dans la mise en œuvre de la perspective actionnelle. https://www.christianpuren.com/mes-travaux/2014b/ accessed 15 April 2020.

Puren, C. (2015). Perspectives actionnelles sur la littérature dans l'enseignement scolaire et universitaire des langues-cultures : des tâches scolaires sur les textes aux actions sociales par les textes. in Vignerob, D., Vandewoude D., Pineira-tresmontant, C., L'enseignement-apprentissage des langues étrangères à l'heure du CECRL : enjeux, 
motivation, implication, Arras (France) : Artois Presses Université. https://www.christianpuren.com/mes-travaux/2015g/accessed 08 July 2019.

Rosen. É. (2010). Perspective actionnelle et approche par les tâches en classe de langue. The Canadian Modern Language Review / La Revue Canadienne des Langues Vivantes, Volume 66, Number 4, June / juin. pp. 487-498, doi : 10.3138/cmlr.66.4.487

Rosen, É., Reinhardt, C. (2010). Le Point sur le Cadre Européen Commun de Référence pour les Langues, Paris: Cle International.

Springer, C. (2010). La dimension sociale dans le CECR : Pistes pour scénariser, évaluer et valoriser l'apprentissage collaboratif. The Canadian Modern Language Review / La Revue Canadienne des Langues Vivantes, 66, 4, 511-523, doi: 10.3138/cmlr.66.4.511.

Yıldırım, A., Simsek, H. (2011). Sosyal Bilimlerde Nitel Arastirma Yöntemleri. Ankara: Seckin Yayincilik.

Yin, R. K. (2009). Case Study Research: Design and Methods (4th Ed.). Thousand Oaks, CA: Sage. 
Creative Commons licensing terms

Author(s) will retain the copyright of their published articles agreeing that a Creative Commons Attribution 4.0 International License (CC BY 4.0) terms will be applied to their work. Under the terms of this license, no permission is required from the author(s) or publisher for members of the community to copy, distribute, transmit or adapt the article content, providing a proper, prominent and unambiguous attribution to the authors in a manner that makes clear that the materials are being reused under permission of a Creative Commons License. Views, opinions and conclusions expressed in this research article are views, opinions and conclusions of the author(s). Open Access Publishing Group and European Journal of Education Studies shall not be responsible or answerable for any loss, damage or liability caused in relation to/arising out of conflicts of interest, copyright violations and inappropriate or inaccurate use of any kind content related or integrated into the research work. All the published works are meeting the Open Access Publishing requirements and can be freely accessed, shared, modified, distributed and used in educational, commercial and non-commercial purposes under a Creative Commons Attribution 4.0 International License (CC BY 4.0). 